\title{
Response to Marco Orrù*
}

* Ibid., 256-257.

Philippe Besnard

\section{OpenEdition}

Journals

Electronic version

URL: http://journals.openedition.org/ress/453

DOI: $10.4000 /$ ress.453

ISSN: $1663-4446$

Publisher

Librairie Droz

\section{Printed version}

Date of publication: 1 March 2004

ISBN: 2-600-00941-8

ISSN: 0048-8046

\section{Electronic reference}

Philippe Besnard, «Response to Marco Orrù* », Revue européenne des sciences sociales [Online], XLII-129 | 2004, Online since 09 November 2009, connection on 19 April 2019. URL : http:// journals.openedition.org/ress/453; DOI : 10.4000/ress.453 
social phenomenon, it is impossible to grasp the true, ultimate nature of the concept which attempts to describe it. In the end we can choose to make the most out of our working concepts and tentative hypotheses, or we can choose instead to recite the requiem aeternam of most sociological theories and concepts. Besnard seems to have made the latter choice.

\section{Philippe BESNARD}

\section{RESPONSE TO MARCO ORRÜ*}

Marco Orrù had an extremely difficult task: to write in praise of the Mertonian theory of anomie. He has acquitted himself as well as he can, but in doing so he is obliged to avoid the simple questions which I have asked of this 'theory', questions which Orrù knows, since he makes reference both to my book and to an earlier article of mine. These questions are, for example: what is the meaning of the word 'anomie' in Merton's writings? Why has Merton never discussed the Durkheimian concept of anomie, while letting us believe that his own analyses both continue and enlarge upon those of Durkheim? What is the meaning of the famous typology of modes of individual adaptation and how coherent is it? To what do these adaptations adapt: is it to an anomic culture or not? Finally, what purpose is served by the term 'anomie' apart from that of a convenient and decorative label? Marco Orrù has taken good care not to take up the challenge that I have thrown down: to define what Merton means by the term 'anomie'. In fact no one has so far succeeded in this: an answer is still awaited.

Instead of conducting a close textual analysis Orrù prefers to adopt a global approach to Merton's writings and to defend them by arguing that it is not necessary to know which of Durkheim and Merton is the 'winner'. Contrary to what he suggests, I have neyer thought that 'straying from the Durkbeimian path would automatically make Merton's theory illegitimate'. In fact I have written exactly the opposite. Everyone is free to define a word as they understand it, on condition that they say in which sense they are using it. Moreover, I am just as critical of the Durkheimian conceptualization as I am of Merton's. Finally, the core of my critique of Merton's essay 'Social Structure and Anomie' is not concerned with this question, even though I $d o$ believe it was important to have demonstrated that the Mertonian concept of anomie - to the extent that one can identify its content and such as it has been generally understood - is opposed to that of Durkheim on all points.

This opposition has nothing to do with the differences outlined by Orrù. Like other commentators, Orrù affirms that Merton locates the origin of human desires in society, while for Durkheim they are supposed to have a biological origin. I must admit to some difficulty in understanding how such a reading of Durkbeim

* $\quad$ Ibid., 256-257. 
is possible. The whole of his discussion of anomie as developed in, for example, Le suicide (1897) and Le socialisme (1928), his whole method of argumentation and all his explanations are based on the idea that human desires are boundless because they are produced by society instead of being, as in the animal world, 'dependent on the body' (1897: 272).

According to Orrù, Merton has been responsible for a further 'revolutionary' innovation: the idea that anomie can be a normal phenomenon. Strange assertion: where can one find the word 'normal' applied to anomie? Not in Merton, but certainly in Durkheim (1897: 285), who devotes an extended passage to anomie institutionalized by, for example, the law on divorce. I would add that the only reference Merton makes to Durkheim in his essay of 1938 (Merton, 1938b: $673 \mathrm{n} 3$ ) is concerned precisely with the well-known theme of the normality of crime.

I am not sure I fully understand what Orrù means when he calls Merton's theory of anomie 'instrumental'. It seems to me that an instrumental theory is one which enables facts to be explained and which can be easily tested against facts. The Mertonian theory of anomie, as I have shown in detail elsewhere (Besnard, 1987: 284-97), has had hardly any resonance in empirical research, apart from ritual references and some refutations towards the end of the 1960s. This is not, in my eyes, an argument against Merton's theory. But I seek in vain for its instrumental character apart from as a pedagogic tool in textbooks.

Sociologists must accept the idea that sociological works, like all products, are subject to the effects of fashion, and that their career depends in good part on the marketing strategies of their promoters. They must also admit that the cognitive power of a theory is not to be measured by its notoriety. Like other celebrated theories, the Mertonian theory of anomie, despite the brilliant intuitions of its author, is like an overinflated balloon which bursts when one tries to seize bold of it. If one believes in sociology and its future, it is not on foundations such as these that one should build. 